\title{
Municipal environmental management and regional conservation in eastern Amazon: perceived performance by public agents in the Pará state, Brazil
}

\author{
Gestão ambiental municipal e conservação regional \\ na Amazônia Oriental: desempenho percebido por \\ agentes públicos no estado do Pará, Brasil
}

Benedito Evandro Barros da Silva ${ }^{1}$

Cláudia Azevedo-Ramos ${ }^{2}$

Hilder André Bezerra Farias ${ }^{3}$

${ }^{1} \mathrm{PhD}$ in Socioenvironmental Development, Environmental Analyst, Secretaria Estadual de Meio Ambiente e Sustentabilidade do Pará (Semas/PA), Marabá, Brazil

E-mail: evandroourem@yahoo.com.br

${ }^{2} \mathrm{PhD}$ in Ecology, Professor, Núcleo de Altos Estudos Amazônicos (NAEA), Universidade Federal do Pará, Belém, Brazil

E-mail: claudia.azevedoramos@gmail.com

${ }^{3}$ PhD in Economics, Adjunct Professor, Department of Economics, Universidade Federal do Pará,

Belém, Brazil

E-mail: hilder@ufpa.br

doi:10.18472/SustDeb.v12n1.2021.39267

Received: 12/08/2021

Accepted: 28/10/2021

ARTICLE - VARIA

\section{ABSTRACT}

Public agents play a key role in municipal environmental management (MEM) under decentralised regimes. This study aimed to evaluate the MEM through the combined perception of municipal agents and the municipal performance previously calculated by secondary data in Pará, Brazil. A questionnaire with a 5-point Likert scale was applied to environmental agents. The respondents $(n=75)$ from 53 municipalities were divided into poorly performing and well-performing municipalities. The perception of agents from poorly performing municipalities was more optimistic than shown by empirical data. Agents from well-performing municipalities prioritised "economic issues" as significant threats to management over the "institutional capacity" chosen by the other group, indicating a broader view of the reality. As the perception over land-use practices was vital to differentiate the agents from different groups, we concluded for the use of mixed monitoring methods and feedback information for agents for a better MEM, focusing on five variables (Rural environmental register - CAR, in Portuguese acronym; degraded area; deforested area; rural credit; and abandoned pasture) that differentiated the municipalities. 
Keywords: Amazon. Environmental performance. Perception. Public management. Sustainability.

\section{RESUMO}

Os agentes públicos desempenham um papel fundamental na gestão ambiental municipal (GAM) em regimes descentralizados. Este estudo objetivou avaliar a GAM por meio da percepção combinada dos agentes municipais e do desempenho municipal previamente calculado por dados secundários no Pará, Brasil. Um questionário com escala Likert de 5 pontos foi aplicado a agentes ambientais. Os respondentes $(n=75)$ de 53 municípios foram divididos em municípios com baixo e bom desempenho. A percepção dos agentes de municípios com baixo desempenho foi mais otimista do que os dados empíricos. Agentes de municípios com bom desempenho priorizaram "questões econômicas" como grandes ameaças à gestão sobre a "capacidade institucional" escolhida pelo outro grupo, indicando uma visão mais ampla da realidade. Como a percepção sobre as práticas de uso do solo foi fundamental para diferenciar os agentes de diferentes grupos, concluímos pelo uso de métodos mistos de monitoramento e informações de feedback para os agentes para uma melhor GAM, com foco em cinco variáveis (Cadastro Ambiental Rural-CAR, área degradada, área desmatada, crédito rural e pastagem abandonada) que diferenciam os municípios.

Palavras-chave: Amazônia. Desempenho ambiental. Percepção. Gestão pública. Sustentabilidade.

\section{INTRODUCTION}

Developing countries still face the challenges of better management of their natural environment, and environmental decentralisation in several countries since the mid-1990s has sought to address this need. However, a review of the topic in 30 countries of Africa and Latin America in the early 2000 s concluded that central governments give local actors the ability to use resources but limited management powers and property rights (AGRAWAL, 2001).

In Latin America, political-administrative decentralisation is an ongoing process (FALLETI, 2010). Brazil, in particular, after a growing pressure on natural resources, intensified decentralisation reforms, especially transferring the environmental management from the central government to the municipal level (VIANA et al., 2016). However, political interference and local fragilities are a constant threat (SCHMITT, SCARDUA, 2015), especially for regional conservation.

In the Brazilian Amazon, environmental management by local government bodies is perceived as a challenge in the face of the substantial threats caused by the traditional model of land use and occupation, which implies the conversion of forestlands into agroecosystems (ASSUNÇÃO; ROCHA, 2014; SILVA; AZEVEDO-RAMOS, 2016). These problems are even more conspicuous in the state of Pará in the Eastern Amazon, where municipal environmental management faces unsustainable use of natural resources motivated by deforestation and land grabbing (VIANA et al. 2016). Pará is a recurring champion of Amazon deforestation (INPE, 2020). Land-use changes, local structural issues and the lack of effective implementation of environmental public policies hamper local environmental management (WEINHOLD; KILLICK; REIS, 2013). The diversity of forms of population occupation, including agricultural settlements, Conservation Units, Indigenous Lands and urban centres of varying sizes, reduces the distances typified in the urban-rural dichotomy, as is proper of the Amazon region (CÔRTES; ÁLVARO DE OLIVEIRA; OJIMA, 2020).

Decentralised environmental public policies have been implemented in Pará as a strategy to control local environmental impacts. Non-compliance by the municipality can be penalised by restricting public credit with consequences for the local economy (ASSUNÇÃO; ROCHA; 2014; SILVA; AZEVEDO-RAMOS, 2016). That requires more effective participation of public agents from local environmental bodies. Municipal environmental agents are key actors in mitigating local environmental problems as they are responsible for licensing and monitoring productive activities (MENDEZ; JÚNIOR, 2018). Ultimately, 
poor local environmental management may threaten regional conservation in several dimensions. Therefore, these agents must understand the reality in which they are immersed and the problems that need to be faced (FERNÁNDEZ-LLAMAZARES et al., 2016).

Environmental perception can be defined as how an individual observes, understands, interprets and evaluates an object of reference, which may be an action, an experience, a policy or a result (BENNETT, 2016). In theory, there should be synergy between empirical results and agents' perception of environmental management performance since they are the protagonists of management planning and implementation. On the other hand, a dissociation between the calculated and perceived performance may have relevant repercussions for maintaining or correcting the adopted municipal strategy. Therefore, although conservation and governance strategies are still underestimated, research on perceptions can influence actions on scales ranging from individual initiatives to national and international policies (BENNETT, 2016).

A good perception of local public agents about the environmental management of their municipalities is crucial, therefore, to improve the planning and the implementation of public policies more efficiently (CELENTANO et al., 2014; DINIZ et al., 2015). However, the responses result from individual cognitive processes, judgments and expectations in the context of positive or negative relationships with the environment and society. By understanding this perception, as well as its sources of satisfaction and dissatisfaction, actions may be planned from the reality of that target audience (LÓPEZ-GAMERO; MOLINA-AZORÍN; CLAVER-CORTÉS, 2010). In a context of shared environmental management (e.g., between states and municipalities) as in the Brazilian Amazon, the understanding of how environmental public-agents perceive their management may become an essential ally for governments in the implementation of the environmental management system (RODRIGUES; MALHEIROS; DAGOSTIN DARÓS, 2012).

Here we offer an innovative approach combining local perceptions and objective evidence of the effectiveness of local environmental management to provide insights into understanding conservation governance outcomes. Previously, Silva, Azevedo-Ramos and Farias (2019) ranked 143 municipalities of the state of Pará in Eastern Amazon according to their environmental management performance using secondary data to calculate a performance index. Empirical data can represent an objective way of evaluating municipal management and contributing to its potential improvement. However, as desirable as it is to measure management objectively, it is necessary to recognise that mathematical models may fail to reveal nuances in the local reality better observed by humans. In this sense, the comparison between calculated performance and local agents' perception about the environmental management of their municipality represents a relevant step in the direction of better understanding and measuring environmental management.

Therefore, this study evaluated Municipal Environmental Management (MEM) through the combined perception of municipal agents and municipal performance previously calculated by secondary data in Pará, Brazil (SILVA; AZEVEDO-RAMOS; FARIAS, 2019). In this context, we addressed the following questions: 1) How do public agents evaluate the environmental management of their municipality? 2) Is there a similarity between the perception of environmental agents and the performance of municipal environmental management calculated by independent secondary data? Finally, we sought to assess the premise that the comparison between the calculated performance and the perception of local agents about the environmental management of their municipality represents a relevant step towards a better understanding and measurement of environmental management. 


\section{METHODS}

\subsection{BACKGROUND}

Pará state is located in eastern Amazon, Brazil. It is the second-largest state in the country, with an area of 1,248,000 km² (3.5 times bigger than Norway) and an estimated population of 8.6 million in 2019 (IBGE, 2020). Pará has a low Human Development Index - HDI (0.646) and occupied the $11^{\circ}$ position in Gross Domestic Product - GDP national ranking. The economy is mainly based on mining, logging, ranching and agriculture.

Silva, Azevedo-Ramos and Farias (2019) previously evaluated the environmental management performance of 143 municipalities in Pará state, from the elaboration of an index calculated through secondary empirical data based on 11 variables associated with management performance (e.g., deforestation rate; land-use changes; life quality, among others). The municipalities could then be ranked according to the performance index of environmental management and divided into performance groups (good; satisfactory; poor; very poor). In this previous study, we also evaluated the effect of 12 variables that potentially influence management (e.g., GDP - Gross Domestic Product, protected areas, rural credit) later used to verify their impact on the calculated performance index.

\subsection{METHODOLOGY}

In the present study, we used variables that were statistically significant on the previous study (see results; Table 3 for a shortlist; and Silva, Azevedo-Ramos and Farias (2019) for a detailed description) as a starting point for the elaboration of a perception questionnaire applied to local agents on the quality of environmental management of their municipality. Furthermore, the previous performance groups of the 143 municipalities based on the ranking of calculated performance were aggregated into two groups: good/satisfactory performing municipalities $(n=72 ; 50.3 \%)$ and very poorly/poorly performing municipalities ( $n=71 ; 49.7 \%$ ). The following analyses evaluated the agents' perception according to the group of municipalities to which they belong.

The target audience was the municipal agents working in the Municipal Environment Secretaries of Pará state. The methodology included 1) the assessment of agents' perceptions around the environmental management of their municipality and 2) a comparison between their perception and the calculated performance for each municipality of Pará.

The perception of municipal agents was evaluated through 360 questionnaires containing 28 questions sent electronically to the 143 municipalities of Pará using the platform Google form in 2018. The questionnaire contained a header explaining the purpose of the study and a free, prior and informed consent for participation and use of the data. Individual information was kept anonymous, and we used only aggregated data. At the same time, we explained the relevance of the research and encouraged the agents' responses by phone. Overall, the survey lasted 60 days. The agents who received the questionnaires were local decision-makers in environmental agencies and/or acted directly in municipal environmental management by appointment of municipal secretariats, which, at their discretion, consider the agent's background suitable for that function. Thus, the assessment of the agent's quality was not part of the scope of this study but rather how he/she interprets environmental management based on his/her perception. The responses of agents from the same municipality were kept as independent samples given the turnover of agents among positions.

First, using two multiple choice questions, interviewees were asked to qualitatively self-evaluate the environmental management of the municipality: a) do not know/without information; b) bad; c) fair; d) good; and e) very good. We also asked the agents to choose the significant threat to environmental 
management in their municipality among the following alternatives: a) incentives for agricultural production; b) low access to communication (telephony; internet); c) low access to information on rural properties; d) low municipal, institutional capacity; e) lack of protected areas; f) high population growth; g) low municipal GDP; h) others (with description).

The agent's perception (26 questions) regarding a given variable associated with environment management in his/her municipality was assessed using a five-point Likert scale: 1 = do not know/ without information; 2 = low; 3 = fair; 4 = high; 5 = very high. We also added variables referring to the legal framework of municipal decentralisation as they describe the instruments for decision making and strengthening of local management. Cronbach's alpha was used to verify the internal coherence of the questionnaire (CRONBACH, 1951). Coherence is considered acceptable for $\alpha \geq 0.7$, which was the case in this study $(\alpha=0.91)$.

For analysis of the questionnaires on a Likert scale (LIKERT, 1932), the option 'do not know/without information' was excluded, and the others renumbered from 1 to 4 . The Student's t-test $(p \leq 0.05)$ was used to compare the differences between the response of each group of municipalities (good performance and poor performance) with the total mean of the questionnaire (1.981). Hypothesis tests were applied to the variables that proved most representative in the agent's perception of environmental management at the municipal level. For t-tests analyses, we considered different hypotheses for the answers depending on the agents' group. For potentially damaging impact variables to management, it is expected that agents from the poorly performing group would assign aboveaverage values (high to very high on the Likert scale). In contrast, agents from the well-performing group would assign below average values (fair to low). In this sense, when the mean answer of a given group of municipalities is equal to the total mean of the questionnaire (1.981), nothing can be concluded regarding the differences between the agents' perceptions. On the other hand, when the mean answer of a group is lower (or ending on the group) than the total mean, there is an agreement (or disagreement, respectively) between the agents' perception and what was expected for their municipality group.

Thus, if $E\left(X_{b}\right)$ is the expected value of a given group of municipalities for a given question and $E\left(X_{q}\right)$ is the expected value of the question for all municipalities (total mean of the questionnaire), for instance, the hypotheses for the well-performing group may be summarised as follows:

$$
\begin{aligned}
& H_{0}: E\left(X_{b}\right)=E\left(X_{q}\right) \text { (nothing can be concluded) } \\
& H_{1}: E\left(X_{b}\right)<E\left(X_{q}\right) \text { (agreement between the agent's perception and the expected) } \\
& H_{2}: E\left(X_{b}\right)>E\left(X_{q}\right) \text { (disagreement between the agent's perception and the expected). }
\end{aligned}
$$

Following the same rationale, for the poorly performing group, the signs would be reversed since the expected would be that the agents assign values above the average for variables with potentially negative impacts.

Then, to compare the answer to each question of the questionnaire between municipalities, we calculated the $d$-value, which means the difference between the mean values of the two groups of municipalities for the same question. Therefore, if $\left[E\left(X_{q, b}\right)\right]$ represents the well-performing group and $\left[E\left(X_{q, r}\right)\right]$ the poorly performing group, then $d=E\left(X_{q, b}\right)-E\left(X_{q, r}\right)$.

Given the increasing values on the Likert scale, it is expected that the agents of the well-performing group assign low values for variables of potentially negative impact to management to their municipality. Thus, if the mean difference between the groups for a given question is zero, nothing can be concluded about the differences between the groups. If the mean difference between the groups for a given question is negative, the agents in the first group attributed a lower value to that variable than the 
agents of the poorly performing group, which agrees with the expected. On the other hand, if the difference between the two groups is positive, the value assigned by the first group would be more significant, therefore, different from expected. Thus, the hypotheses were summarised as:

$$
\begin{aligned}
& \mathrm{H}_{0}: d=0 \text { (nothing can be concluded) } \\
& \mathrm{H}_{1}: d<0 \text { (agreed with the expected perception) } \\
& \mathrm{H}_{2}: d>0 \text { (disagreed with expected perception) }
\end{aligned}
$$

\section{RESULTS}

\subsection{PERCEPTION OF ENVIRONMENTAL AGENTS}

Overall, 74 municipal agents from 53 municipalities, representing $37.1 \%$ of 143 municipalities of Pará, responded to the questionnaires (Table 1). Of these, 41 (56\%) agents were from the well-performing

\begin{tabular}{|c|c|}
\hline Municipalities with good performance & Poor performing municipalities \\
\hline $\begin{array}{c}\text { Acará, Altamira, Anapu, Augusto Corrêa, Aveiro, } \\
\text { Bagre, Baião, Barcarena, Benevides, Bonito, } \\
\text { Bragança, Bujaru, Curuá, Faro, Itaituba, Jacareacanga, } \\
\text { Maracanã, Marapanim, Novo Progresso, Quatipuru, } \\
\text { Rurópolis, Santa Bárbara do Pará, Santarém, } \\
\text { Santarém Novo, Senador José Porfírio, Tailândia, } \\
\text { Uruará. }\end{array}$ & $\begin{array}{c}\text { Brasil Novo, Breu Branco, Cachoeira do Piriá, Canaã dos } \\
\text { Carajás, Capanema, Capitão Poço, Castanhal, Concórdia } \\
\text { do Pará, Dom Eliseu, Floresta do Araguaia, Irituia, Jacundá, } \\
\text { Marabá, Ourém, Palestina do Pará, Piçarra, Placas, Santa } \\
\text { Luzia do Pará, Santa Maria das Barreiras, Santa Maria do } \\
\text { Pará, Santana do Araguaia, São Francisco do Pará, Terra Alta, } \\
\text { Tucuruí, Vitória do Xingu, Xinguara. }\end{array}$ \\
\hline
\end{tabular}
group and $33(44 \%)$ from the poorly performing group.

Table 1 | Municipalities of Pará that participated in the study of performance in environmental management.

Source: The authors; and Silva, Azevedo-Ramos and Farias (2019) for performing groups

During this research, most agents qualified the management of their municipality as good $(n=31$; $41.9 \%$ ) or fair ( $n=27 ; 36.5 \%$ ) regardless of the performance rating of the municipality (Table 2 ). Only 7 agents (21.2\%) from the poorly performing group rated their municipality as having poor management, while 15 agents from this group rated as having very good or good management. On the other hand, most agents from the well-performing group $(n=22 ; 53.7 \%)$ classified their municipality as having good management. Still, 16 agents (39\%) classified it as just fair (Table 2 ). Thus, the agents from the poorly performing group had a perception different from that previously calculated for their municipality. The same occurred with the agents of the other group but to a lesser extent.

Table 2 | Qualification of the municipal environmental management by local agents divided into previously classified groups in Pará, Brazil.

\begin{tabular}{cccccc}
\hline $\begin{array}{c}\text { Group of the } \\
\text { interviewee }\end{array}$ & Very good & Good & Fair & Bad & Total \\
\hline $\begin{array}{c}\text { Well-performing } \\
\text { municipalities } \\
\begin{array}{c}\text { Poorly performing } \\
\text { municipalities }\end{array}\end{array}$ & $1(2.44 \%)$ & $22(53.66 \%)$ & $16(39.02 \%)$ & $2(4.88 \%)$ & $41(100 \%)$ \\
\hline Total & $6(18.18 \%)$ & $9(27.27 \%)$ & $11(33.33 \%)$ & $7(21.21 \%)$ & $33(100 \%)$ \\
\hline
\end{tabular}


Overall, the agents indicated institutional and economic issues as the major threats to environmental management (Figure 1 ). The agents $(n=41)$ from the well-performing municipalities prioritised threats of economic nature (21.4\% incentive to agricultural production; and $19 \%$ low GDP) over institutional ones (19\% low institutional capacity). In turn, the agents $(n=33)$ from the poorly performing municipalities chose options predominantly related to institutional issues ( $27.3 \%$ low institutional capacity and $18.2 \%$ low access to information on rural properties).

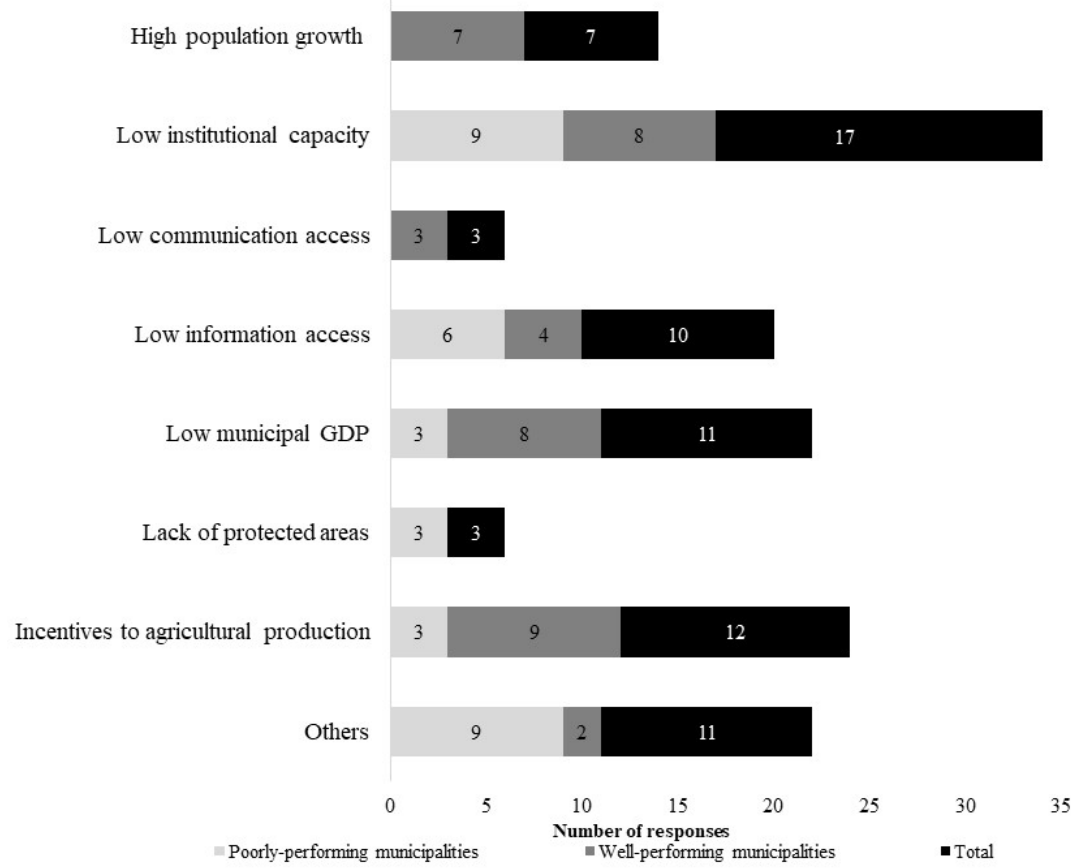

Figure 1 | Threats to municipal environmental management according to local agents based on survey.

Source: The authors.

The descriptive statistics of answers to the questionnaire with the Likert scale can be seen in Table 3 . Among the variables of potential positive impact on management, the agents from the well-performing group scored highest on the number of City Hall officials and the presence of protected areas. On the other hand, among the variables of potentially negative impact, none was classified as high in their municipalities. On the contrary, the highest variables were close to fair in their opinion (pasture, secondary vegetation and burned areas).

Table 3 | The responses of the environmental agents by groups of municipalities (mean, SD = standard deviation; and $n=$ number of samples). Response options on the Likert scale: 1 (low) to 4 (very high).

\begin{tabular}{|c|c|c|c|c|c|c|}
\hline \multirow[b]{2}{*}{ Negative effect variables } & \multicolumn{3}{|c|}{$\begin{array}{l}\text { Well-performing } \\
\text { municipalities }\end{array}$} & \multicolumn{3}{|c|}{$\begin{array}{l}\text { Poorly performing } \\
\text { municipalities }\end{array}$} \\
\hline & Mean & $S D$ & $n$ & Mean & $S D$ & $n$ \\
\hline Infant mortality & 1.31 & 0.48 & 29 & 1.24 & 0.72 & 17 \\
\hline Abandoned pasture & 1.34 & 0.79 & 29 & 1.70 & 0.82 & 27 \\
\hline Rural credit & 1.46 & 0.54 & 26 & 1.90 & 0.44 & 20 \\
\hline Rural environmental register & 1.83 & 0.72 & 40 & 2.67 & 0.62 & 30 \\
\hline Increased deforestation & 1.84 & 0.96 & 37 & 1.69 & 0.90 & 29 \\
\hline Agricultural area & 1.84 & 0.90 & 38 & 1.79 & 0.90 & 29 \\
\hline
\end{tabular}




\begin{tabular}{|c|c|c|c|c|c|c|}
\hline \multirow[b]{2}{*}{ Negative effect variables } & \multicolumn{3}{|c|}{$\begin{array}{l}\text { Well-performing } \\
\text { municipalities }\end{array}$} & \multicolumn{3}{|c|}{$\begin{array}{l}\text { Poorly performing } \\
\text { municipalities }\end{array}$} \\
\hline & Mean & $S D$ & $n$ & Mean & $S D$ & $n$ \\
\hline Deforested area & 1.85 & 0.84 & 34 & 2.53 & 0.91 & 30 \\
\hline Degraded area & 1.92 & 0.71 & 38 & 2.50 & 0.69 & 28 \\
\hline Pasture area & 2.16 & 0.76 & 38 & 2.59 & 0.58 & 29 \\
\hline Secondary vegetation & 2.24 & 1.03 & 37 & 2.38 & 0.95 & 29 \\
\hline Burned area & 2.27 & 0.73 & 37 & 2.13 & 0.81 & 30 \\
\hline Partial mean & 1.82 & 0.77 & 34.8 & 2.10 & 0.76 & 27.1 \\
\hline Positive effect variables & Mean & DP & $\mathrm{n}$ & Mean & DP & $\mathrm{n}$ \\
\hline Paid environmental fines & 1.24 & 0.50 & 34 & 1.45 & 0.78 & 29 \\
\hline Green tax & 1.39 & 0.73 & 36 & 1.61 & 0.79 & 28 \\
\hline Intensification of livestock & 1.67 & 1.11 & 39 & 2.41 & 0.74 & 29 \\
\hline Internet access & 1.71 & 0.58 & 41 & 1.88 & 0.64 & 20 \\
\hline Demographic density & 1.74 & 0.67 & 34 & 1.58 & 0.62 & 31 \\
\hline Environmental fund & 1.78 & 0.93 & 36 & 1.66 & 0.81 & 29 \\
\hline Quality of life & 1.81 & 0.65 & 42 & 1.84 & 0.80 & 31 \\
\hline Telephony access & 1.86 & 0.78 & 42 & 2.41 & 0.71 & 32 \\
\hline Environmental surveillance & 1.93 & 0.69 & 41 & 2.14 & 0.88 & 29 \\
\hline City Hall council & 2.07 & 1.22 & 41 & 2.19 & 1.11 & 31 \\
\hline Population growth & 2.27 & 0.73 & 37 & 1.79 & 0.69 & 28 \\
\hline Institutional capacity & 2.37 & 0.77 & 41 & 2.47 & 1.01 & 30 \\
\hline Environmental laws & 2.41 & 0.81 & 41 & 2.68 & 0.91 & 31 \\
\hline City hall officials & 2.50 & 0.72 & 32 & 2.38 & 0.65 & 24 \\
\hline Protected areas & 2.68 & 0.75 & 37 & 1.54 & 0.78 & 28 \\
\hline Partial mean & 1.96 & 0.77 & 38.3 & 2.00 & 0.79 & 28.7 \\
\hline
\end{tabular}

Source: The authors.

For the agents from the poorly performing group, environmental laws and the institutional capacity received the highest scores among variables with a potentially positive effect on management (between fair and high). Among the variables of potentially negative impact, the highest scores were for the rural environmental register, pasture area and deforested/degraded area (near high). It is worth noting that the Rural Environmental Registry was included in the group of variables with a potentially negative impact given a temporary speculative increase in deforestation after its creation in 2012 (AZEVEDO et al., 2017).

Considering aggregated responses for all variables, there was a significant difference $(t=-3.30$; $d$.f. $=1553 ; p=0.001$ ) between the two groups of municipalities (Figure 2a). When analysing only the responses for the variables of potentially negative effect on management, there was a significant difference in perception between the two groups of municipalities $(t=-4.43$; d.f. $=440 ; p<0.001$; Figure $2 \mathrm{~b}$ ). Agents from the poorly performing group attributed higher values to these variables than agents from the well-performing group. However, when analysing only the responses for the variables with potentially positive effects on management, there were no significant differences between the responses of the two groups of municipalities $(t=-0.7$; d.f. $=930 ; p=0.484$; Figure $2 c)$, indicating that the agents similarly scored these variables in the two groups of municipalities.

Thus, variables of potentially negative impact on management were vital to differentiate agents' perceptions regarding the management of their municipality. Therefore, these variables will be analysed in more detail next. 


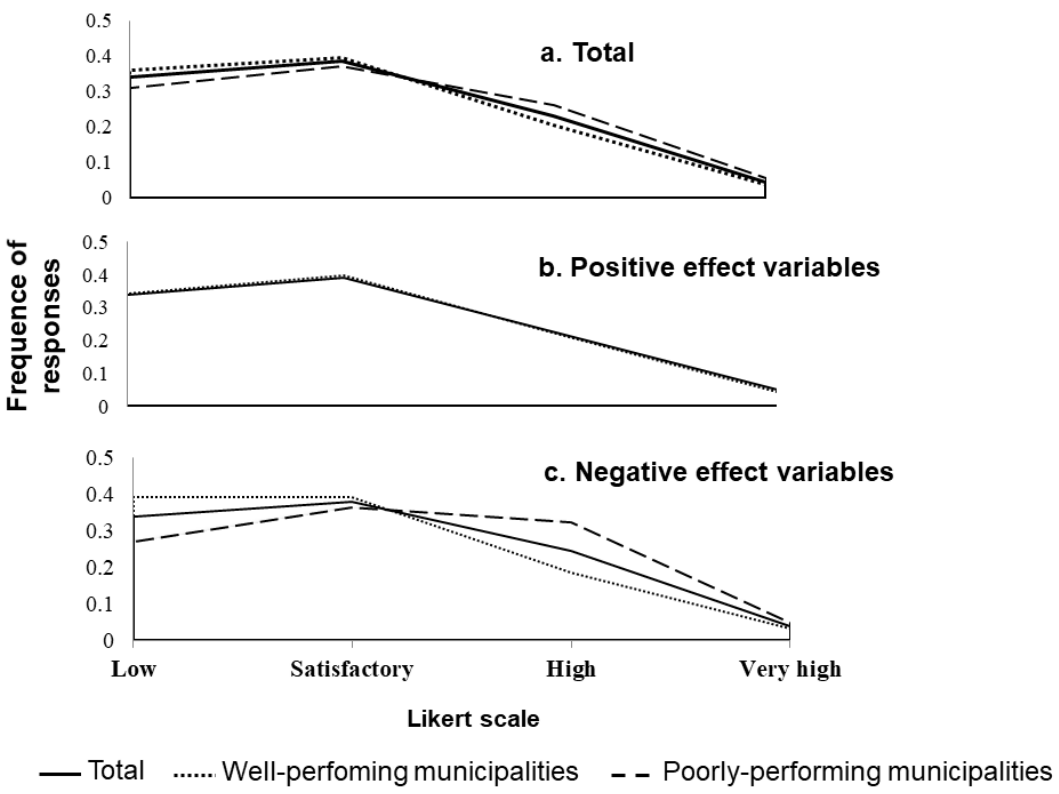

Figure 2 | Distributions of the agents' answers by municipal performance groups: a) all variables; b) potentially positive impact variables; and c) potentially damaging impact variables.

Source: The authors.

\subsubsection{KEY VARIABLES IN THE PERCEPTION OF MUNICIPAL ENVIRONMENTAL MANAGEMENT}

As the variables of potentially negative effect to environmental management presented significant differences between the responses of the two groups of municipalities, only this group of variables was used in the hypothesis test.

There were three variables (abandoned pasture, infant mortality and rural credit) in which the perception of agents from the well-performing group coincided with what is expected for their municipalities $\left(H_{1}\right)$, that is, below average values (Table 4a). However, for seven variables, there were no differences in the total mean of the questionnaires. Therefore nothing could be concluded.

There were five variables (degraded area, secondary vegetation; deforested area; pasture area and rural environment register) in which the perception of agents from the poorly performing group were within the expected for their municipalities $\left(\mathrm{H}_{1}\right)$, that is, above average values, challenging the environmental management in these municipalities.

Only one variable in each group was different from expected $\left(\mathrm{H}_{2}\right)$ : secondary vegetation higher than average in the well-performing group and infant mortality lower than average in the poorly performing group (Table 4a).

In sum, of the 11 variables associated with land-use assessed, $27.3 \%(n=3)$ were perceived as expected for well-performing municipalities (i.e., below average), and $45.5 \%(n=5)$ for the poorly performing municipalities (i.e., above average). One variable for each group was perceived differently than expected (secondary vegetation for the former and infant mortality for the latter group). About $64 \%$ ( $n$ $=7)$ and $45 \%(n=5)$ of the variables had inconclusive results for well-performing and poorly performing municipalities, respectively. 
Then, we calculated the $d$-value, which means the difference between the mean values of the two groups of municipalities for the same question (Table $4 b$ ): $\mathrm{H}_{0}: d=0$ (nothing can be concluded) $\mathrm{H}_{1}: d<$ 0 (agreed with the expected perception); $\mathrm{H}_{2}: d>0$ (disagreed with expected perception). Five variables (rural environmental register, degraded area, deforested area, rural credit and abandoned pasture) agreed with the expected (Table $4 \mathrm{~b}$ ). That means the agents from the well-performing group assigned lower values to these variables in their municipalities than the other group agents. In addition, this second hypothesis test helped show the trend for some variables where nothing could be concluded $\left(\mathrm{H}_{0}\right)$ in the first test (Table 4a), such as the degraded area, deforested area, and rural environmental register the well-performing group.

Table 4 | Hypothesis tests for the perception of agents considering only variables with potentially negative effects on management. See text for hypothesis in " $a$ " and " $b$ ".

a - within performance group

\begin{tabular}{|c|c|c|c|c|c|c|}
\hline \multirow[b]{2}{*}{ Variable } & \multicolumn{3}{|c|}{$\begin{array}{l}\text { Well-performing } \\
\text { municipalities }\end{array}$} & \multicolumn{3}{|c|}{$\begin{array}{l}\text { Poorly performing } \\
\text { municipalities }\end{array}$} \\
\hline & $t$ & $p$ & Hypothesis & $t$ & $p$ & Hypothesis \\
\hline Degraded area & -0.525 & 0.602 & $\mathrm{HO}$ & 3.952 & 0.001 & $\mathrm{H} 1$ \\
\hline Deforested area & -0.784 & 0.438 & $\mathrm{HO}$ & 3.359 & 0.002 & $\mathrm{H} 1$ \\
\hline Increased deforestation & -1.204 & 0.236 & $\mathrm{HO}$ & -1.951 & 0.061 & HO \\
\hline Burned area & 1.945 & 0.060 & $\mathrm{HO}$ & 0.923 & 0.364 & $\mathrm{HO}$ \\
\hline Crop area & -1.091 & 0.283 & $\mathrm{HO}$ & -1.241 & 0.225 & $\mathrm{HO}$ \\
\hline Pasture area & 1.057 & 0.297 & $\mathrm{HO}$ & 3.443 & 0.002 & $\mathrm{H} 1$ \\
\hline Abandoned pasture & -7.091 & 0.000 & $\mathrm{H} 1$ & -1.995 & 0.057 & $\mathrm{HO}$ \\
\hline Secondary vegetation & 2.200 & 0.034 & $\mathrm{H} 2$ & 3.443 & 0.002 & $\mathrm{H} 1$ \\
\hline Infant mortality & -6.678 & 0.000 & $\mathrm{H} 1$ & -7.039 & 0.000 & $\mathrm{H} 2$ \\
\hline Rural envir. register & -1.270 & 0.212 & $\mathrm{HO}$ & 5.275 & 0.000 & $\mathrm{H} 1$ \\
\hline Rural credit & -4.559 & 0.000 & $\mathrm{H} 1$ & -0.571 & 0.575 & $\mathrm{HO}$ \\
\hline
\end{tabular}

b - difference ( $d$-value) between the mean values of the two groups of municipalities

\begin{tabular}{cccccc}
\hline Variable & Difference $(d)$ & $t$ & $V$ & P-value & Hypothesis* \\
\hline Rural envir. register & -0.84 & -4.70 & 65.39 & 0.00 & $\mathrm{H} 1$ \\
Degraded area & -0.58 & -3.31 & 59.17 & 0.00 & $\mathrm{H} 1$ \\
Deforested area & -0.68 & -2.93 & 61.74 & 0.00 & $\mathrm{H} 1$ \\
Rural credit & -0.44 & -2.39 & 38.86 & 0.02 & $\mathrm{H} 1$ \\
Abandoned pasture & -0.36 & -2.16 & 44.90 & 0.04 & $\mathrm{H} 1$ \\
Pasture area & -0.43 & -1.77 & 62.68 & 0.08 & $\mathrm{H} 0$ \\
Secondary vegetation & -0.14 & -0.82 & 63.40 & 0.41 & $\mathrm{H} 0$ \\
Crop area & 0.05 & 0.25 & 59.26 & 0.81 & $\mathrm{H} 0$ \\
Infant mortality & 0.08 & 0.51 & 39.47 & 0.61 & $\mathrm{H} 0$ \\
Burned area & 0.14 & 0.62 & 62.24 & 0.54 & $\mathrm{H} 0$ \\
Increased deforestation & 0.15 & 0.77 & 57.04 & 0.44 & $\mathrm{H} 0$ \\
\hline
\end{tabular}

Source: The authors. 


\section{DISCUSSION}

Environmental decentralisation policies were implemented in the municipalities of Pará to improve the quality of local environmental management (ASSUNÇÃO; ROCHA, 2014; BORGES DE LIMA; BUSZYNSKI, 2011; NEPSTAD et al., 2014; VIANA et al., 2016). Economic incentives and a better legal definition of municipal environmental decentralisation were responsible for a greater adherence of municipalities to the decentralised management regime, which increased from 10 municipalities in 2009 to 123 in 2019 (SILVA; AZEVEDO-RAMOS, 2016). In turn, municipalities had to evolve to a more sustainable local development model and a better management performance. That demanded greater responsibility and effective participation of local agents in controlling deforestation and strengthening the municipal environmental systems of Pará (NEVES; WHATELY, 2016; VIANA et al., 2016). However, the monitoring of municipal environmental management did not occur at the same speed as the adherence to the decentralised regime.

According to Fowler (2018), State or intergovernmental management approaches shape how local governments interact and how much influence local managerial efforts have on policy outcomes, leading to different local managerial perceptions and agency effectiveness. With the evolution of the political-administrative decentralisation, local governments tend to gain maturity and authority to manage programs to meet local needs and national standards, interacting voluntarily with other administrative levels and managing shared goals (AGRANOFF; MCGUIRE, 2001; ALLIK; REALO, 2004). As local environmental impacts may have transboundary effects, affecting the state's socioeconomics, a joint effort from local governments is necessary to achieve a greater good. In practice, at the beginning of a decentralisation process, however, local environmental public agents should have a clear stateled orientation towards their goals to narrow the spectrum of their judgments about priorities that otherwise may result in different inter-municipal performances. This is rarely the case in Amazon municipalities, leading to a mix of different outcomes regarding environmental management. In this sense, the balance that allows a decentralised regime not to depart from the common good, in this case, effective environmental management in the municipalities, has yet to be experienced in the Amazon. Likewise, the lack of comparison instruments to assess the evolution of municipalities and plan corrective measures undermines the quality of local environmental management (MOLDAN; JANOUŠKOVÁ; HÁK, 2012; TANGUAY et al., 2010). Continuous monitoring would also enable a better perception of agents in the short, medium and long term, allowing learning throughout the process.

In this study, public agents qualified the municipal environmental management (usually, good or fair) differently from that expected based on the group to which the agent belongs (according to the previous study by Silva, Azevedo-Ramos and Farias (2019). The agents from well-performing municipalities tended to underestimate their management slightly. In turn, the agents from the poorlyperforming group saw their municipalities more optimistically than reality. It is noteworthy that this group of municipalities was also the one that received the most incentives to improve the quality of its management (SILVA; AZEVEDO-RAMOS, 2016), such as local agents training and equipment acquisition (e.g. vehicles, motorcycles, computers) financed by the Amazon Fund and the State Environmental Fund. The injection of financial and institutional incentives without verified compliance may also induce a false perception by local agents that the municipality improved its management.

Furthermore, the lack of feedback from monitoring systems for agents may cloud their judgment regarding the quality of management in their municipality (CRIOLLO; MALHEIROS; ALFARO, 2019). Moreover, the diversity of management objectives has proven to complicate decision-making processes when accounting for stakeholders' views (HAMILTON; SALERNO, 2020). Similarly, socioeconomic tradeoffs of land-use change may bias the perception of environmental impacts (CÓRDOBA et al., 2019).

Agents perceived the institutional and economic deficiencies of the municipalities as threats to environmental management, which may hinder the transition to the decentralised regime in Pará (SILVA; AZEVEDO-RAMOS, 2016). However, the agents of the two groups of municipalities prioritised 
different threats: institutional capacities (conjunctural causes) for the poorly performing group; and economic issues (structural causes) for the well-performing group. The lack of institutional capacity in the Amazon municipalities is undeniable but transversal to all municipalities and, therefore, not enough to explain differences in performance. Structural causes may demand a better understanding of agents between proximal and ultimate causes. However, the agents of the poorly performing group seemed to miss (or underestimate) the effect of economic factors (such as incentives to agriculture and low GDP of municipalities) on environmental management compared to good performers. Perception results from a different set of factors, such as political, demographic, socioeconomic, biophysical, among others (BENNETT, 2016; GUTHIGA, 2008). In this case, it seems that a broader perception of the local conjuncture may lead to better management.

Overall, the variables with potentially positive effects on management used in this study denote conditions for structured management (e.g., infrastructure, credit, employees, institutional capacity). Agents of the two groups showed similar perceptions about these variables, assigning low values to them. That means that the agents from all municipalities were working under suboptimal conditions according to their perception. On the other hand, agents' perception about the variables of potentially negative impact to management was vital to differentiate the groups. The magnitude of these variables mainly described the output of management actions (e.g., deforestation, fire outbreaks, degraded area). Therefore, what may be influencing the management performance is the predominant type of land-use practices in each municipality. These findings may contribute to improving local environmental management by enhancing the control or mitigation of land-use changes. Furthermore, this measure involves a better understanding by agents about the impacts of unsustainable practices on environmental management, which may be clouded when these are the most common practice in a given municipality.

Of the 11 variables associated with land-use changes, $27.3 \%$ were perceived as expected for wellperforming municipalities (i.e., changes below average), and $45.5 \%$ for the poorly performing municipalities (i.e., changes above average). Those results might suggest that conspicuous changes are easier to identify by agents, while discrete ones may go unnoticed. Therefore, the joint monitoring by empirical data may contribute to reinforcing warnings before it is harder to reverse the problem. Overall, the agents attributed values consistent with what was expected for their group of municipalities for five variables: rural environmental register, degraded area, deforested area, rural credit and abandoned pasture. In other words, the agents were able to assess their municipalities concerning these variables satisfactorily. The similarity between an agent's perception and the empirical analysis, in this case, suggests that the monitoring of these specific variables may result in greater effectiveness in choosing strategies for improving environmental management. For instance, in municipalities with poor environmental performance, monitoring actions focused on the five variables may improve the municipality's performance.

\section{CONCLUSION}

In conclusion, the agents' perception about the overall quality of the management of their municipality was different from that expected for their performance group. Land-use practices were relevant to distinguish the two groups of municipalities. Taken together, the impact of economic activities in each municipality may challenge the local environmental management.

The results highlighted the importance of incorporating perception as evidence for improving conservation and governance policies. The relevance of incorporating perception was also shown in other studies with different thematic (BICKLEY et al., 2020; CARMENTA et al., 2017; OKUMAH, YEBOAH, 2020). Although the agents' opinions do not necessarily reflect the institutional opinion, their perception about municipal environmental management may be an ally for a quick assessment of the quality of management. On the other hand, a misperception of reality may undermine better environmental 
management. In this way, mixed methodologies, which allow monitoring the management with the active participation of environmental agents and empirical data, may be more effective in assessing the quality of management.

This study demonstrated that the agents' perception of the municipal environmental management might not fully agree with the results of municipal performance previously calculated from secondary data (SILVA; AZEVEDO-RAMOS; FARIAS 2019). Better incorporation of diversified monitoring and information feedback to these agents may improve local environmental governance. To reduce costs, public environmental agencies could focus first on the variables that the agents attributed values consistent with what was expected for their group of municipalities: rural environmental register (CAR), degraded area, deforested area, rural credit and abandoned pasture.

These findings may be helpful in decision-making processes in environmental management on a large scale. It also highlights the importance of including human factors before implementing a policy, mainly through capacity building/training of public agents. The empowered local social capital may be an ally in identifying solutions to problems, significantly increasing the effectiveness of environmental policies.

\section{ACKNOWLEDGMENTS}

This study received partial support (Ph.D. scholarship) from the National Council for Scientific Development and Technology (CNPq) to the first author. We thank the municipal environmental agents of Pará state, Brazil, who agreed to collaborate in this study. David Oren made valuable comments and reviewed the English version of the manuscript.

CONFLICT OF INTEREST: The authors declare that they have no conflicts of interest.

\section{REFERENCES}

AGRANOFF, R.; MCGUIRE, M. American Federalism and the Search for Models of Management. Public Administration Review, v. 61, n. 6, p. 671-681, nov. 2001.

AGRAWAL, A. The Decentralizing State: nature and origins of changing environmental policies in Africa and Latin America, 1980-2000. Paper prepared for the 97th Annual Meeting of the American Political Science Association, San Francisco, August 30 to September 2. 2001.

ALLIK, J.; REALO, A. Individualism-collectivism and social capital. Journal of Cross-Cultural Psychology, v. 35, p. 29-49, 2004.

ASSUNÇÃO, J.; ROCHA, R. Getting greener by going black: the priority municipalities in Brazil. Rio de Janeiro, Brazil: Climate Policy Initiative, 2014.

AZEVEDO, A. A. et al. Limits of Brazil's Forest Code as a means to end illegal deforestation. Proceedings of the National Academy of Sciences, v. 114, n. 29, p. 7653-7658, 2017.

BENNETT, N. J. Using perceptions as evidence to improve conservation and environmental management: perceptions and conservation. Conservation Biology, v. 30, n. 3, p. 582-592, nov. 2016.

BICKLEY, S. M. et al. Human perceptions of and interactions with wild canids on cattle ranches in central Brazil. Oryx, v. 54, n. 4, p. 546-553, nov. 2020.

BORGES DE LIMA, I.; BUSZYNSKI, L. Local environmental governance, public policies and deforestation in Amazonia. Management of Environmental Quality: An International Journal, v. 22, n. 3, p. 292-316, nov. 2011.

CARMENTA, R. et al. Perceptions across scales of governance and the Indonesian peatland fires. Global Environmental Change, v. 46, p. 50-59, nov. 2017. 
CELENTANO, D. et al. Perceptions of environmental change and use of traditional knowledge to plan riparian forest restoration with relocated communities in Alcântara, Eastern Amazon. Journal of Ethnobiology and Ethnomedicine, v. 10, n. 1, p. 11, nov. 2014.

CÓRDOBA, D. et al. Understanding local perceptions of the impacts of large-scale oil palm plantations on ecosystem services in the Brazilian Amazon. Forest Policy and Economics, v. 109, p. 102007, 2019.

CÔRTES, J. C.; ÁLVARO DE OLIVEIRA, D.; OJIMA, R. Urbanização Extensiva e Reconfiguração Rural na Amazônia: uma proposta teórico-metodológica baseada em indicadores environment. Governance and Development Extended Urbanization and Rural Reconfiguration in the Amazon: a Theoretical-Methodological Prop. p. 1-25, 2020

CRIOLLO, R.; MALHEIROS, T.; ALFARO, J. F. Municipal Environmental Management Indicators: a bottom-up approach applied to the colombian context. Social Indicators Research, v. 141, n. 3, p. 1037-1054, nov. 2019.

DINIZ, F. et al. Mapping future changes in livelihood security and environmental sustainability based on perceptions of small farmers in the Brazilian Amazon. Ecology and Society, v. 20, n. 2, p. 26, nov. 2015.

FALLETI, T. G. Decentralization and Subnational Politics in Latin America. Cambridge: Cambridge University Press, 2010.

FERNÁNDEZ-LLAMAZARES, Á. et al. Local perceptions as a guide for the sustainable management of natural resources: empirical evidence from a small-scale society in Bolivian Amazonia. Ecology and Society, v. 21, n. 1, p. 2, nov. 2016.

FOWLER, L. Local Managerial Perceptions of Intergovernmental Management. State and Local Government Review, v. 50, n. 1, p. 6-14, nov. 2018.

GUTHIGA, P. M. Understanding Local Communities' Perceptions of Existing Forest Management Regimes of a Kenyan Rainforest. International Journal of Social Forestry, v. 1, n. 2, p. 145-166, 2008.

HAMILTON, M.; SALERNO, J. Cognitive Maps Reveal Diverse Perceptions of How Prescribed Fire Affects Forests and Communities. Frontiers in Forests and Global Change, v. 3, p. 75, nov. 2020.

INSTITUTO BRASILEIRO DE GEOGRAFIA E ESTATÍSTICA. Cidades. Rio de Janeiro, Brazil: Instituto Brasileiro de Geografia e Estatística, 2020. Available in: https://cidades.ibge.gov.br/brasil/pa/panorama.

INSTITUTO NACIONAL DE PESQUISAS ESPACIAIS. Projeto Prodes: Banco de dados de desmatamento nos municípios. São José dos Campos, São Paulo, Brazil: Instituto Nacional de Pesquisas Espaciais, 2020. Available in: http://www.dpi.inpe.br/prodesdigital/prodes.php.

LIKERT, R. A technique for the measurement of attitudes. Archives of psychology, v. 22, n. 140, 1932, 55p.

LÓPEZ-GAMERO, M. D.; MOLINA-AZORÍN, J. F.; CLAVER-CORTÉS, E. The potential of environmental regulation to change managerial perception, environmental management, competitiveness and financial performance. Journal of Cleaner Production, v. 18, n. 10-11, p. 963-974, nov. 2010.

MENDEZ, G. DE P.; JÚNIOR, R. A. F. C. Obstacles to municipal environmental licensing: analysis of the main difficulties and obstacles in the environmental licensing procedures of municipalities. Ciência e Natura, v. 40, n. 0, p. 35, nov. 2018

MOLDAN, B.; JANOUŠKOVÁ, S.; HÁK, T. How to understand and measure environmental sustainability: indicators and targets. Ecological Indicators, v. 17, p. 4-13, nov. 2012.

NEPSTAD, D. et al. Slowing Amazon deforestation through public policy and interventions in beef and soy supply chains. Science, v. 344, n. 6188, p. 1118-1123, nov. 2014.

NEVES, E. M. S. C.; WHATELY, M. Municipalities and policies against deforestation in the Brazilian Amazon. Novos Estudos Cebrap, v. 106, p. 67, 2016. 
OKUMAH, M.; YEBOAH, A. S. Exploring stakeholders' perceptions of the quality and governance of water resources in the Wenchi municipality. Journal of Environmental Planning and Management, v. 63, n. 8, p. 1375-1403, nov. 2020.

RODRIGUES, M. L.; MALHEIROS, T. F.; DAGOSTIN DARÓS, T. A percepção ambiental como instrumento de apoio na gestão e na formulação de políticas públicas ambientais. Saúde e Sociedade, v. 21, p. 96-110, 2012.

SCHMITT, J.; SCARDUA, F. P. A descentralização das competências ambientais e a fiscalização do desmatamento na Amazônia. Revista de Administração Pública, v. 49, n. 5, p. 1121-1142, nov. 2015.

SILVA, B. E. B. DA; AZEVEDO-RAMOS, C. Evolução da Descentralização da Gestão Ambiental Municipal no Estado do Pará. In: Desafios Amazônicos. (PEZZUTI, J.; AZEVEDO-RAMOS, C.). Série Desenvolvimento e Sustentabilidade. Belém, Brazil: NAEA Editora, 2016. p. 261-296.

SILVA, B. E. B. DA; AZEVEDO-RAMOS, C.; FARIAS, H. A. B. The impact of decentralization policies: the environmental performance applied to municipalities of the Amazon. Desenvolvimento e Meio Ambiente, v. 51, p. 202-223, 2019.

TANGUAY, G. A. et al. Measuring the sustainability of cities: an analysis of the use of local indicators. Ecological Indicators, v. 10, n. 2, p. 407-418, nov. 2010.

VIANA, C. et al. How does hybrid governance emerge? Role of the elite in building a green municipality in the Eastern Brazilian Amazon. Environmental Policy and Governance, v. 26, n. 5, p. 337-350, 2016.

WEINHOLD, D.; KILLICK, E.; REIS, E. J. Soybeans, Poverty and Inequality in the Brazilian Amazon. World Development, v. 52, p. 132-143, nov. 2013. 